\title{
Anti-ENPP3/MMAF Antibody-Drug Conjugate AGS-16M8F
}

National Cancer Institute

\section{Source}

National Cancer Institute. Anti-ENPP3/MMAFAntibody-Drug Conjugate AGS-16M8F. NCI

Thesaurus. Code C116626.

An antibody-drug conjugate (ADC) containing a human immunog lobulin (Ig) G2k

monoclonal antibody (AGS-16C) directed against the ectonucleotide

pyrophosphatase/phosphodiesterase family member 3 (ENPP3, NPP3, B10, PDNP3

CD203c, or PD-IBETA ), conjugated, via the non-cleavable maleimidocaproyl (mc) linker, to monomethyl auristatin $\mathrm{F}(\mathrm{MMAF})$, an auristatin derivative and a potent microtubule inhibitor, with potential antineoplastic activity. Upon intravenous administration of antiENPP3/MMAF ADC AGS-16M8F, the monoclonal antibody moiety selectively binds to ENPP3 expressed on tumor cells; upon internalization, the ADC is degraded by lysosomal proteases and MMAF is released. In turn, MMAF binds to and inhibits tubulin polymerization, which results in G2/M phase arrest and tumor cell apoptosis. While normally expressed at low levels in the proximal tubules of the kidney, the type II transmembrane glycoprotein ENPP3 is overexpressed in most renal neoplasms and some liver cancers. 